\title{
Online investigation for irrigation water quality parameters of Gummidipoondi Lake, Thiruvallur, Tamil Nadu, India
}

\author{
Bharath Singh Jebaraj ${ }^{1}\left[\right.$ Vijayalakshmi Sankaran $^{1} \cdot$ Sushmitha Sivasankaran $^{2}$
}

Received: 18 February 2021 / Accepted: 30 September 2021 / Published online: 10 February 2022

(c) The Author(s) 2022

\begin{abstract}
The water quality parameters analysis was carried out in the Gummidipoondi Lake located in Thiruvallur district of Tamil Nadu, India. As the Lake was only source for the farmers for irrigation in their place, contamination of the Lake is the major threat. The contamination factors for that Lake are mainly due to the manufacturing industries which are present around the water body. Farming is the only occupation of the surroundings. In order to protect the water body which is serving as a backbone for that community, a complete analysis is carried out to monitor the water quality parameters. Currently, offline investigation is carried out by the water supply and drainage board. The junior water analyst will directly inspect the water bodies, collect samples and do testing either in laboratories or in field using the kits available. The sets of data will be available after completing a number of tests and displayed in the website by manual entry. In order to carry a real-time analysis and the direct providing of data in the website, an online investigation method is implemented and tested in the Gummidipoondi Lake. The main parameters of this lake water are the temperature, $\mathrm{pH}$ and the turbidity. This concept uses real-time processors with sensors, connecting protocols and the display of results in the web interface. The results produced by the method are used to provide the contamination happened in the lake and alert the public works department to take necessary action to avoid the contamination. The outputs are displayed in the website to give current updates about the condition of the Gummidipoondi Lake.
\end{abstract}

Keywords Gummidipoondi Lake $\cdot$ Chemical analysis $\cdot$ Turbidity $\cdot \mathrm{pH} \cdot \mathrm{IoT}$

\section{Introduction}

Water is an important input to agriculture. For any crops or plantations in agriculture, water is a carrier of nutrients from the soil to the plants. The entire hydraulic process of plants depends on water. The crops generally consume the ground water available. Absence or shortage of ground water needs irrigation. Irrigation can be done using the nearby wells, lakes and rivers. Tamil Nadu in India is the agricultural state. Over the wide agriculture area, maize is cultivated mostly in the range of $6549 \mathrm{~kg} / \mathrm{ha}$ and rice in $3918 \mathrm{~kg} / \mathrm{ha}$. Other than these top producers, sugarcane, groundnut, oil seeds, cotton,

Bharath Singh Jebaraj

j.bharathsingh@gmail.com

1 Department of Electronics and Instrumentation Engineering, R.M.K. Engineering College, Gummidipoondi, Tamil Nadu, India

2 Department of Instrumentation Engineering, Madras Institute of Technology, Chennai, Tamil Nadu, India coconut, plantations and food grains are also produced in the state of Tamil Nadu.

Tamil Nadu is the major source of food grains to the other states. Tamil Nadu stands top in production of maize, cumbu, groundnut and oil seeds. It stands second in rice, coconut and cereals. The study area comes under the northeastern zone of TN. The soil types of the study area are red sandy loam, clay loam and saline coastal alluvium which are suitable for rice production and horticulture. $70 \%$ of the land in the study area is utilized for the production of rice, and the remaining $30 \%$ of the land is used for horticulture. More than $80 \%$ of the population in the area are farmers, and their main source of income is agriculture. The population in the study area is 5876 . The proportion of males and females is same in the New Gummidipoondi village.

Gummidipoondi village receives most of the rainfall from October to December from the north-east monsoon. The rainfall will be more in these months, and most of the lakes and rivers in the surrounding will be filled. The water in the lakes will be utilized for the remaining months. The lake 
water is the most important source of agriculture in the New Gummidipoondi village. The rainfall in the state is getting reduced due to many factors like deforestation, greenhouse gas emissions, industries, etc. New Gummidipoondi village comes under the district of Thiruvallur. Around 11\% depreciation is happening in the rainfall every year (Fig. 1).

The water stored in the lakes is used for the irrigation purpose. This lake water is getting polluted due to the industries present in the area. Major production industries like power plants, construction, food products, electrical and electronics sector, and tanneries are present in the New Gummidipoondi. The effluents from the industries are diverted to the nearby lake which causes contamination of the water body. The water from the study lake is only used for the irrigation purpose, and the contamination of the lake will lead to several problems like non-availability of water during the non-rainfall seasons and the contaminated water will damage the crop production and fertility of the soil. All the cycles present in the ecosystem of earth contain soil as a controlling element. Polluting land will damage the entire ecosystem of mankind. Lose of fertility, soil erosion and reduced ground water level are the main problems due to polluting of land. To prevent land from polluting, the water provided must also be a non-contamination commodity (Table 1).

Thamarai Eaari (Thamarai Lake) is the name of the lake which is the study area of the proposed work. It is the biggest lake in Gummidipoondi. The location coordinates of
Table 1 Yield of various corps in Tamil Nadu

\begin{tabular}{ll}
\hline National level crop & $\begin{array}{l}\text { Yield in Tamil } \\
\text { Nadu (Kg/ha) }\end{array}$ \\
\hline Maize & 6549 \\
Cumbu & 2613 \\
Groundnut & 2509 \\
Total Oilseeds & 2230 \\
Cotton & 442 \\
Coconut & 9238 \\
Rice & 3918 \\
Sugarcane(MT) & 103 \\
Sunflower & 1089 \\
Jowar & 1558 \\
Coarse cereals & 3759 \\
Food grains & 3090 \\
Total pulses & 689 \\
\hline
\end{tabular}

the study area are $13^{\circ} 25^{\prime} 1^{\prime \prime} \mathrm{N} 80^{\circ} 7^{\prime} 27^{\prime \prime} \mathrm{E}$. The parameters of water like $\mathrm{pH}$, temperature and conductivity are studied at regular intervals, and the published data are analyzed for the water quality of the lake. $\mathrm{pH}$ is the hardness measurement and has the standard value of 7 . Anything higher or lower will be marked as acidic or alkaline. Many methods are available for measuring the $\mathrm{pH}$ levels in liquids. The colorimetric method is the simplest method which uses indicator

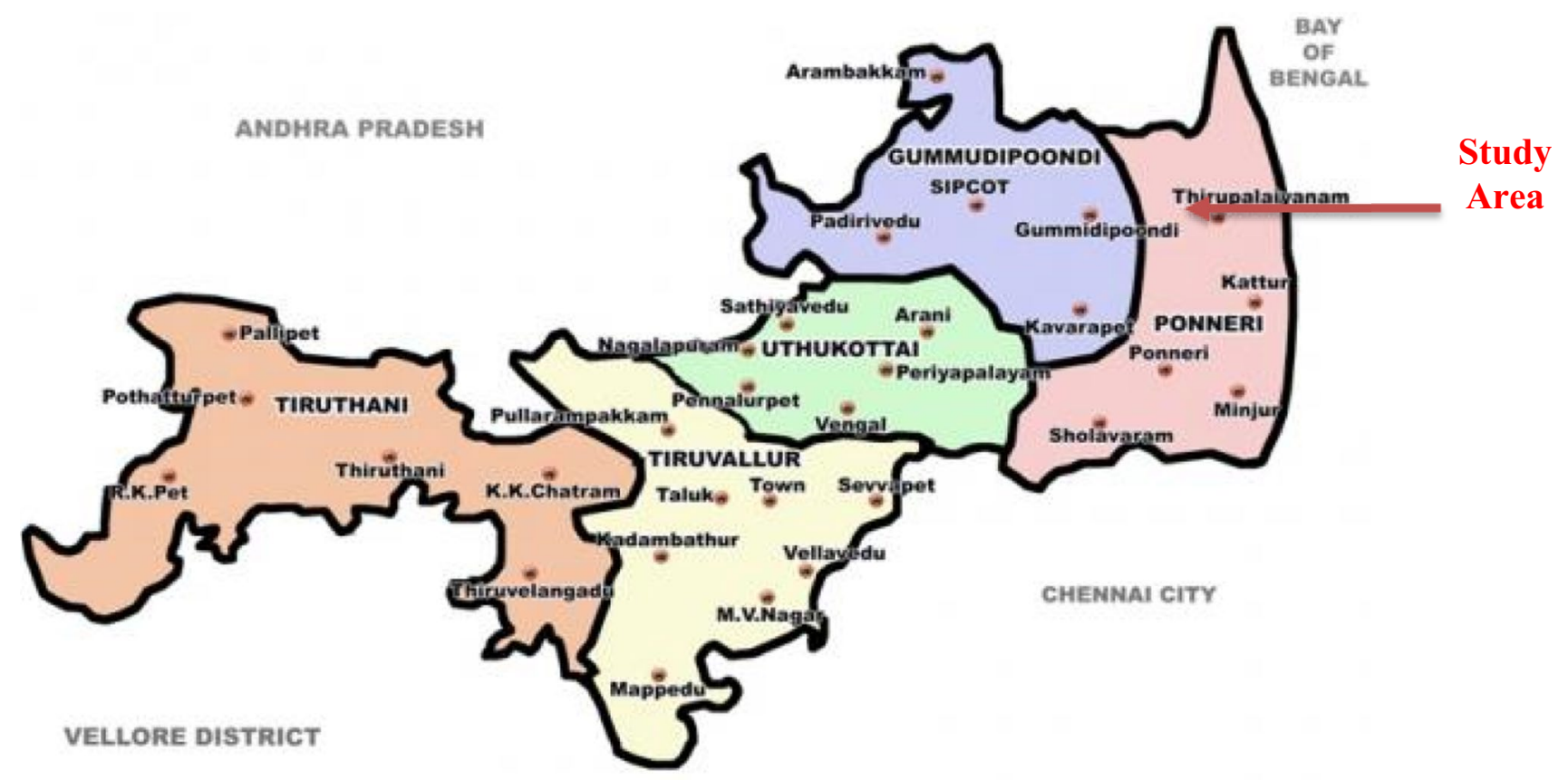

KANCHEEPURAM DISTRICT

Fig. 1 Map of the study area-Gummidipoondi Village 
solutions or papers to detect the levels. The results of this method are not accurate. The next method is the usage of electrodes to measure the $\mathrm{pH}$ level (Webster 2003). Nowadays, the evolution of sensor makes this job easier. The $\mathrm{pH}$ sensors now available have the wide measuring range up to $14 \mathrm{pH}$ and the accuracy is $\pm 0.1 \mathrm{pH}\left(25^{\circ} \mathrm{C}\right)$ and the response time is $\leq 1 \mathrm{~min}$. Temperature is an important factor as it changes the chemical reactions happening in the water. As the study area has some rocks inside its bed, the temperature effects are more in this lake. The adverse effects of temperature will melt the minerals deposited on the rocks, and this creates a different chemical reactions. The dissolved oxygen content is drastically changed due to the temperature. The average temperature of the study area is $34^{\circ} \mathrm{C}$ which has a significant effect on the water bodies. Many methods are employed to measure the temperature like thermometer, resistance temperature gauges, etc. We have used the temperature sensor DS18B20. It is advanced sensor with the measurement range of -55 to $125^{\circ} \mathrm{C}\left(-67^{\circ} \mathrm{F}\right.$ to $\left.+257^{\circ} \mathrm{F}\right)$ and has a simple connectivity.

One more parameter taken into consideration is the ions present in the study area. It is called as water conductivity. The conductivity depends on the amount of salt present in the water. Since our study area is the rain water accumulated, the conductivity is generally low. But the impurities from the industries and dumping of waste which has potassium $(\mathrm{K}+)$, magnesium $(\mathrm{Mg}+)$, sodium $(\mathrm{Na}+)$, carbonate $(\mathrm{CO} 2-)$, chloride (Cl-) and sulfate ( $\mathrm{SO} 2-$ ) have a very bad impact on the water bodies. We have used the turbidity sensor which uses light transmittance and scattering rate and the fastest response time of $<500 \mathrm{~ms}$.

We have made the research paper in this order. The related works to the water quality assessment in various places like Telangana are listed in the literature study. The block diagram of the method used and the major components are discussed. The impact of $\mathrm{pH}$, temperature, conductivity and turbidity are measured in real time using this model in the Thamarai Lake, Gummidipoondi, and the whole data are analyzed in the form of charts and tables. The data are uploaded in the website, and the user is made available with the data anywhere and anytime.

\section{Literature survey}

Adimalla et al. (2020) assessed the quality of groundwater in hard rock terrain of Medak, a fast-urbanizing region of Telangana State, South India, using Geographic Information System (GIS) and groundwater quality index (GWQI) techniques. Spatial distribution maps are generated for $\mathrm{pH}$, electrical conductivity (EC), total dissolved solids (TDS), total hardness $(\mathrm{TH})$, calcium $(\mathrm{Ca} 2+)$, magnesium $(\mathrm{Mg} 2+)$, sodium $(\mathrm{Na}+)$, potassium $(\mathrm{K}+)$, bicarbonate $(\mathrm{HCO} 3-)$, chloride ( $\mathrm{Cl}-$ ), sulfate (SO42-), nitrate (NO3-) and fluoride $(\mathrm{F}-)$ evidenced that the ground water quality is enslaved by geogenic and anthropogenic activities. Jasrotia et al. (2012) studied the ground water prospects in the Western Doon valley to delineate the groundwater potential and groundwater quality zones suitable for domestic purposes based on the integrated use of Remote Sensing and Geographical Information Systems (GIS). The groundwater prospects map has been prepared by integrating the hydrogeomorphologic, land use/land cover from satellite data and drawdown maps using index overlay method in the GIS environment.

Avtar Singh Jasrotia et al. (2018) carried out the hydrogeochemical investigation using the 50 groundwater samples collected from dug well and tube well in the Western Doon valley to comprehend the geochemistry of the groundwater and the results of hydro-geochemical are helpful to generate the baseline information and roadmap for future research on groundwater resources to assess the water quality in relation to agricultural and domestic uses in the Western Doon valley. Adimalla et al. (2020) investigated the Irrigational and drinking suitability of groundwater in the semiarid region of central Telangana, India, and results highlighted that most of the groundwater is suitable for drinking purposes based on $\mathrm{pH}$, electrical conductivity (EC), total dissolved solids (TDS), total hardness (TH) as $\mathrm{CaCO} 3$, calcium $(\mathrm{Ca} 2+)$, magnesium $(\mathrm{Mg} 2+)$, sodium $(\mathrm{Na}+)$, potassium $(\mathrm{K}+)$, chloride $(\mathrm{Cl}-)$ and sulfate (SO42-). Irrigational suitability of groundwater is assured in the study area through sodium adsorption ratio (SAR), sodium percentage (\%Na), residual sodium carbonate (RSC), magnesium hazard ratio (MHR), and Kelly ratio (KR) results.

Gopal Krishan et al. (2020) analyzed the data related to salinity, isotopes, land-use and land cover (LULC) along with field and laboratory experimental results of central Punjab and addressed the apprehension related to the rise in groundwater salinity and its subsequent ingression in the fresh-water zone. Harish Bisht et al. (2021) examined the ionic and physical properties of Gangotri glacier meltwater as well as the prominent weathering process to determine the sources of solute. Ajay kumar Taloor et al. (2020) analyzed the $\mathrm{pH}$, electrical conductivity (EC), total dissolved solids (TDS), total hardness (TH), calcium $(\mathrm{Ca} 2+)$, magnesium $(\mathrm{Mg} 2+)$, sodium $(\mathrm{Na}+)$, potassium $(\mathrm{K}+)$, bicarbonate ( $\mathrm{HCO} 3-)$, sulfate $(\mathrm{SO} 42-)$, chloride $(\mathrm{Cl}-)$, nitrate $(\mathrm{NO} 3-)$, and fluoride $(\mathrm{F}-)$ in the samples collected from three kinds of terrain (mountainous, hilly and plain) to calculate the quality of spring water for irrigation purposes.

Daud et al. (2017) did a study of various water samples in Pakistan, and the comparison is done with the standards. The sewerage water (fecal) mixing with drinking water is the major contaminant. The human-made problems like pesticides, industrial wastes, fertilizers and 
other chemicals degraded the water quality in an increased extent. Usage of filters in the water entering area will give a minimal solution to contamination. The various methods and analysis discussed by the author helped in analyzing the lake water data of study area. Satyam Srivastava et al. (2018) improved the water quality detection system connectivity. He used the $\mathrm{pH}$ and the TDS datasheet of standard and old derived models and developed a Bluetooth-based system. This system can send SMS and Email. The location can be traced by this system using Google maps. This system used a low-cost basic microcontroller. For interfacing with the Bluetooth and other applications, this system needs analog-to-digital converters and extra memories which make the embedded system little bulky. Zheng and Yuanling (2011) proposed a remote sensingbased water quality management system. They used data from remote sensing, ground-based observation and environmental background data. They automated the processing of collection of remote sensing and ground data. They included the change of method in water quality monitoring and analysis.

Many methods are currently available for the monitoring of the water quality parameters. Basic portable microcontroller-based water quality measurement (Eline Boelee et al. 2019) is available without storage and wireless sensor-based rural drinking water monitoring system. Wireless sensor networks-based rural drinking water monitoring system is available with various modes and hubs (Vijay 2016). Floating boat with sensors inbuilt can be used in water bodies to determine the health of the water and the availability of mobile updating (Jachimowski 2017). Currently using methods can be advanced with machine learning, and the water quality parameters can be enhanced (Siti Hajar Bt Ali et al. 2015).

Remote sensing techniques can also be employed for measuring the water quality parameters like unwanted deposits, dissolved organic matter in different colors, chlorophyll content and different pollutants, and the data collected will be more, which can be used for further analysis. Pollution due to tanneries located near the belts of Cauvery River is analyzed by various laboratory methods, and the results are tabulated (Manoj Kumar et al. 2012). Advanced webbased analyzer for water quality is available, and the results can be visualized as tabulations, graphs and charts (Dirisu et al. 2016). Gummidipoondi, the industrial place, has main three lakes called Poondi, Red Hills and Sholavaram. Adding to the above, there are many small lakes which get water from rainfall. The Thamarai Lake is the biggest among all the lakes. The study area has many mineral water plants which use the ground water and lake water as their sources. This area has around 390 industries, and now it turns to landfill site from the nearby districts like Chennai, Thiruvallur and Kancheepuram. The waste includes solvents, used oils, organic waste, battery effluent liquid and many. The annual rainfall of the study area is $1000 \mathrm{~mm}$.

\section{Proposed model design and development}

An automated water quality analysis method is designed using the sensors and the processor. The disadvantages of traditional and the most practiced method for long years are discussed, and the advancement in the proposed method is mentioned. The designed method is used for the water analysis in the Thamarai Lake, Gummidipoondi study area. The complete analysis of the lake water is studied for the duration of three months, and the complete analysis and simulations are done. The precautionary steps are taken according to the results. The proposed method overcomes the direct method of collection of water samples. The samples are analyzed in the laboratory. Many methods like physicochemical water analysis using chemical analysis, biological monitoring and microbiological analysis are done in the laboratories. If the contamination is more, then cultivation process will be done. This laboratory process will take more days, and the real-time data are not available. This traditional method is vulnerable to more errors. The gross errors and the instrument errors must be taken into consideration. Some advanced methods are available in the market which uses the microcontroller. The controller is interfaced with the sensors which will detect the water quality parameters like $\mathrm{pH}$, temperature, humidity and conductivity. The model may be wired or wireless depending upon need. The results may be either displayed in LCD, or web interface is possible using necessary protocols and interfaces.

The usage of microcontrollers helps in the easy interfacing of the inputs and outputs. The inputs here mentioned are the sensors, and the results display units like LCD and LED come under outputs. Earlier, the basic microcontroller was used and did not have extensions like Wi-Fi interfacing and lacked communication protocols like Bluetooth, Zigbee and Internet of Things and the conversion blocks like analog-todigital and digital-to-analog converters and memories are to be interfaced externally. Now the available microprocessors and controllers have a wide range of memories and converters interfaced in the single chip. This saves more space and cost. The water quality can be determined by various parameters, but the main parameters which constitute $85 \%$ of the water quality depend on $\mathrm{pH}$, turbidity and conductivity. The research on the above parameters provides better results (Fig. 2).

\section{Specifications of the study area}

The study area was chosen very near to our academic institution. The entire model is modelled, designed and built 
Fig. 2 Existing topology for water quality assessment

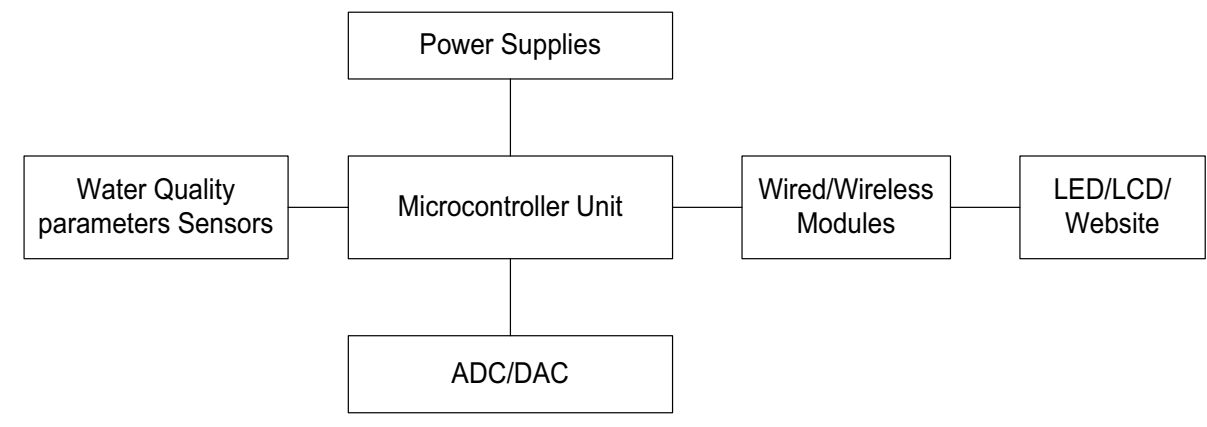

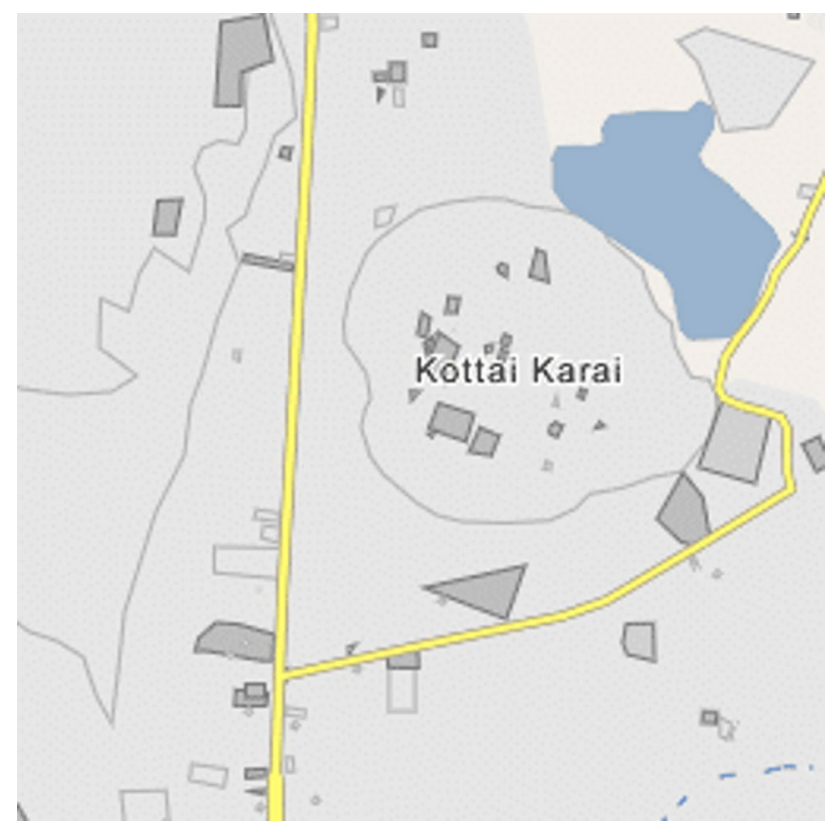

Fig. 3 Aerial view of the study area

in-house and implemented in the beds of Thamarai Lake, Gummidipoondi, and the results are validated. The location of the study area is located in the district of Thiruvallur, Tamil Nadu, India. The location is represented as $13^{\circ} 25^{\prime} 1 " \mathrm{~N}, 80^{\circ} 7^{\prime} 27^{\prime \prime} \mathrm{E}$. This lake gets the source of water from the rain. It is the major source of water for domestic and agricultural purpose. The study area is generally flooded during the rainy season, and the water is stored for future purpose. This lake is fully covered with algae and blooms which made the water polluted. After a long demand from the surroundings, the lake was cleaned and it came under the control of water control board. But still, the water is getting polluted due to human activities and industries. To make aware of the water quality and the parameters, this system is proposed and tested.
Gummidipoondi is the hot place, and the temperature will be more during summer and moderate during the remaining periods (Fig. 3).

\section{Modelling of proposed system}

The proposed model is built with three different types of sensors, namely $\mathrm{pH}$ sensor, turbidity sensor and the temperature sensor. Temperature sensor is not commonly used for water analysis. But the study area is very hot, and the effect of temperature on the study area is more. Moreover the study area has rocks on the lake bed. Many minerals will be present in the rocks. Due to heavy temperature, the minerals will get dissolved and it will be mixed with the lake water. Effect of temperature is the must condition taken into account for the study area. The processor used is Raspberry 3 which is the advanced model with an inbuilt web interface. The data will be available anytime and anywhere to anyone. For increasing the security features, a username and a password are provided for the administrator. Also the results are tabulated and displayed in charts. We have used the standard levels of 6.5 to 8.5 for $\mathrm{pH}, 25-40{ }^{\circ} \mathrm{C}$ for temperature and $>100$ NTU for turbidity. The processor selected is the low-cost, high-efficiency controller. The main advantage of using this processor is the availability of Bluetooth, Wi-Fi and the most powerful central processing unit and graphics processing unit. The used processor is easily coded by anyone, and it is user-friendly.

A web page is created with a username and a password. Authentication is provided for security reasons. The user can get a real-time data after sign-in into the web browser. Many options are provided like change of password and export and import data. Exporting of data helps for analysis in multi-ways. Importing of data is also possible of comparing the current results with previous results. The web page is already dumbed with graph creators. The sensor values can be plotted against time for all the parameters. The three 


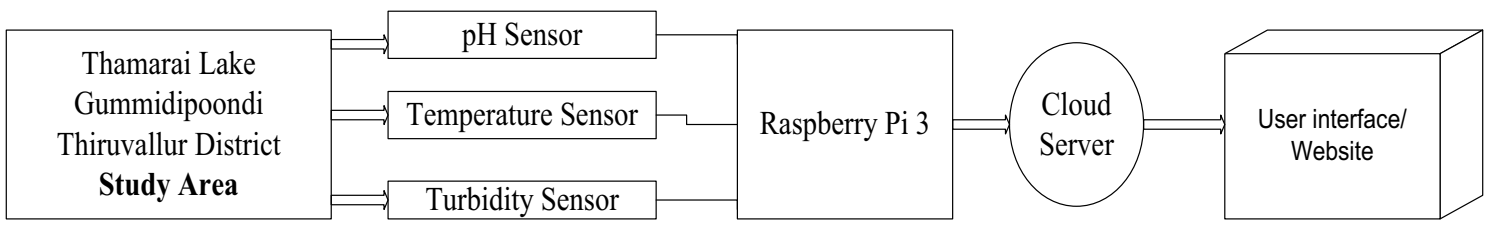

Fig. 4 General layout of the model proposed
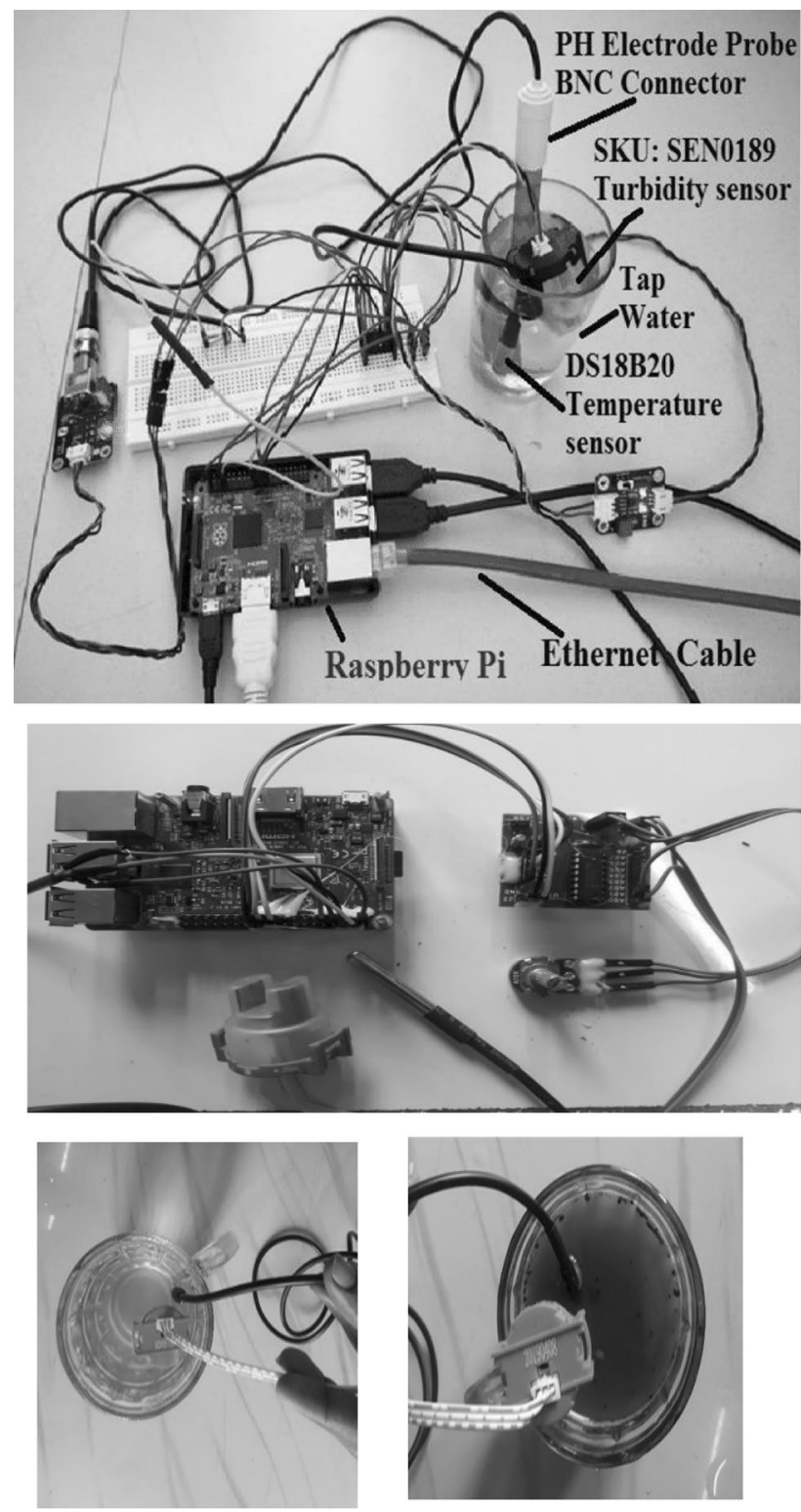

Fig. 5 Hardware setup of proposed model

values of the work $\mathrm{pH}$, temperature and conductivity can be displayed in a same graph or separately depending on demand (Fig. 4).
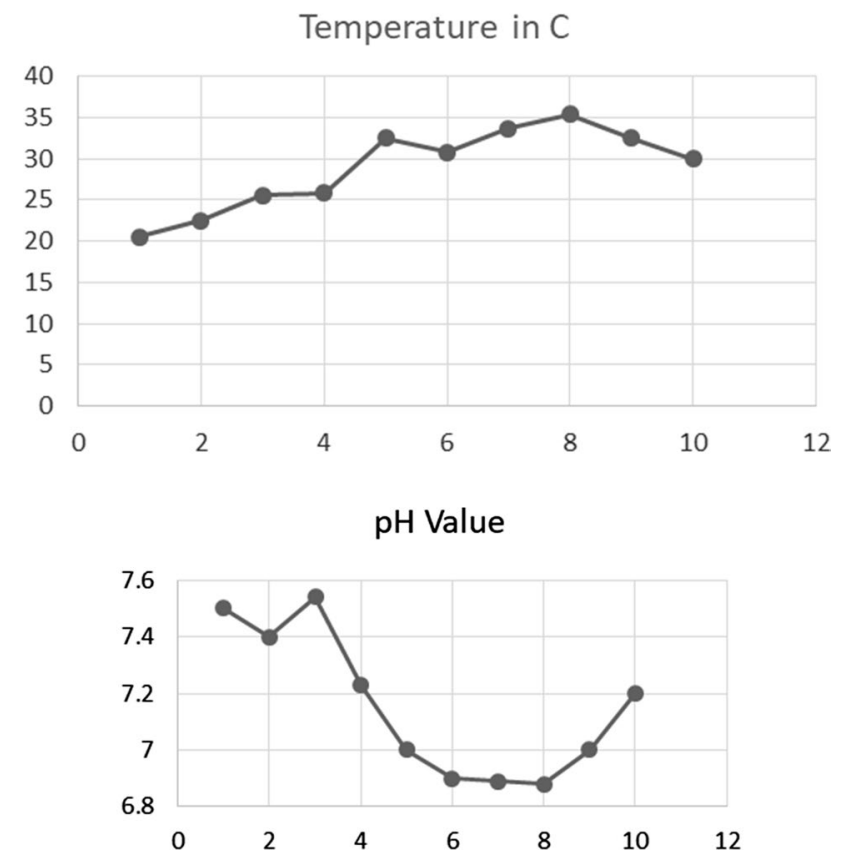

Fig. 6 Temperature and $\mathrm{pH}$ chart

\begin{tabular}{|c|c|c|c|c|}
\hline $\log \mid \mathrm{D} \uparrow \downarrow$ & DATA $\downarrow$ & Temp & Turbidity $\downarrow$ & $\mathrm{PH}$ \\
\hline 331 & $\begin{array}{l}\text { Ph } \\
\text { Alert... }\end{array}$ & 37.6648754274548 & 32.687 & 9.960918417195897 \\
\hline 332 & $\begin{array}{l}\mathrm{Ph} \\
\text { Alert... }\end{array}$ & 0.04885197850512668 & 32.75 & 9.990229604298975 \\
\hline 333 & $\begin{array}{l}\text { Ph } \\
\text { Alert... }\end{array}$ & 41.08451392281387 & 32.687 & 9.980459208597948 \\
\hline 334 & $\begin{array}{l}\mathrm{Ph} \\
\text { Alert... }\end{array}$ & 10.60087933561309 & 32.687 & 10.0 \\
\hline 335 & $\begin{array}{l}\text { Ph } \\
\text { Alert... }\end{array}$ & 3.85930630190523 & 32.687 & 10.0 \\
\hline
\end{tabular}

Fig. $7 \mathrm{pH}$ alert table

\section{Hardware model}

The hardware components are assembled, and testing is done using the normal tap water. The system is working perfect, and it is ready for implementing in the river beds of Thamarai Lake, Gummidipoondi (Fig. 5). 

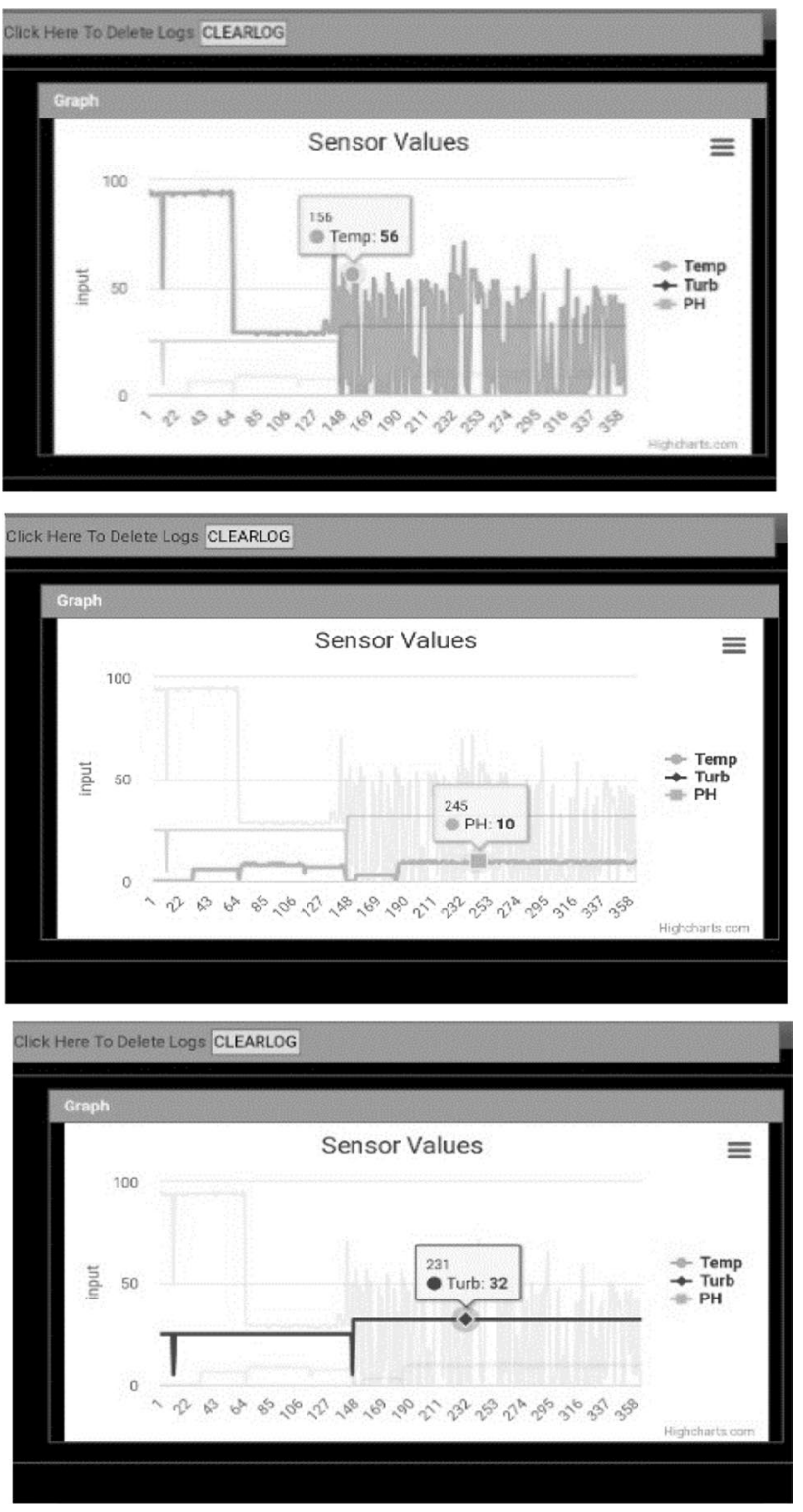

Fig. 8 Graphical representation of the measured values

\section{Results and Discussion}

The analysis of water quality was done for a month, and more data are collected related to temperature, $\mathrm{pH}$ and turbidity of the study area. The temperature recorded are tabulated, and the chart is provided (Figs. 6, 7, 8).

To view individual parameter log, graph is also plotted with timely data of parameters and thus historical trends are collected. For example, the below graph shows $\mathrm{pH}$, turbidity and temperature graphs are plotted (Tables 2, 3).
Table 2 Temperature readings of the study area

\begin{tabular}{ll}
\hline Entry No & $\begin{array}{l}\text { Tem- } \\
\text { perature } \\
\text { in C }\end{array}$ \\
\hline 1 & 20.5 \\
2 & 22.5 \\
3 & 25.6 \\
4 & 25.8 \\
5 & 32.5 \\
6 & 30.8 \\
7 & 33.7 \\
8 & 35.4 \\
9 & 32.5 \\
10 & 30 \\
\hline
\end{tabular}

\section{Conclusion}

The complete analysis of the water quality parameters happened for a month in the beds of Thamarai Lake, Gummidipoondi Taluk, Thiruvallur district, Tamil Nadu, India. From the analysis, the parameter temperature has its adverse effects on the study area because of the rocks present in the lake. Due to this, there is a heavy variation of $\mathrm{pH}$, conductivity and other values. The pollution from the industries also has a serious effect on the quality of water. Providing realtime, discrete data helps the public to understand the quality parameters, and an awareness camp is conducted nearby to explain how their lake water is getting polluted and the ways to prevent it. This work is focused on developing a cost-effective water quality monitoring system. The disadvantages of the existing system are overcome by using the proposed system. A complete water surveillance report can be produced to the pollution control board, and the necessary actions can be proposed for stopping pollution. This work removes the overall human intervention.
Table $3 \mathrm{pH}$ readings of the study area

\begin{tabular}{ll}
\hline Day & pH value \\
\hline 1 & 7.5 \\
2 & 7.4 \\
3 & 7.54 \\
4 & 7.23 \\
5 & 7 \\
6 & 6.9 \\
7 & 6.89 \\
8 & 6.88 \\
9 & 7 \\
10 & 7.2 \\
\hline
\end{tabular}


In the future, many sensors can be added to find out dissolved oxygen and bacterial growth.

Acknowledgements The authors would like to thank the management of R.M.K. Engineering College for providing the required resources.

Author Contributions BSJ was involved in conceptualization; BSJ and VSL were involved in methodology; BSJ and SAS were involved in hardware and software; BSJ and SAS were involved in validation; BSJ collected data; BSJ and SAS were involved in writing —original draft preparation; VSL was involved in writing-review and editing.

All authors have read and agreed to the published version of the manuscript.

Funding The author(s) received no specific funding for this work.

\section{Declarations}

Conflict of interest The authors declare that they have no conflicts of interest to report regarding the present study.

Human and animal rights statement This chapter does not contain any studies with human participants or animals performed by any of the authors.

Open Access This article is licensed under a Creative Commons Attribution 4.0 International License, which permits use, sharing, adaptation, distribution and reproduction in any medium or format, as long as you give appropriate credit to the original author(s) and the source, provide a link to the Creative Commons licence, and indicate if changes were made. The images or other third party material in this article are included in the article's Creative Commons licence, unless indicated otherwise in a credit line to the material. If material is not included in the article's Creative Commons licence and your intended use is not permitted by statutory regulation or exceeds the permitted use, you will need to obtain permission directly from the copyright holder. To view a copy of this licence, visit http://creativecommons.org/licenses/by/4.0/.

\section{References}

Adimalla N, Ajay Kumar T (2020) Hydrogeochemical investigation of groundwater quality in the hard rock terrain of South India using Geographic Information System (GIS) and groundwater quality index (GWQI) techniques. Groundw Sustain Dev. https://doi.org/ 10.1016/j.gsd.2019.100288

Adimalla N, Ratnakar D (2020) Appraisal of groundwater quality for drinking and irrigation purposes in Central Telangana, India. Groundw Sustain Dev. https://doi.org/10.1016/j.gsd.2020.100334

Ajay Kumar T, Rayees A (2020) Spring water quality and discharge assessment in the Basantar watershed of Jammu Himalaya using geographic information system (GIS) and water quality Index(WQI). Groundw Sustain Dev. https://doi.org/10.1016/j. gsd.2020.100364

Artur J (2017) Factors Affecting Water Quality in a Water Supply Network. J Ecol Eng. https://doi.org/10.12911/22998993/74288

Chimezie D, et al (2016) Level of $\mathrm{pH}$ in drinking water of an oil and gas Producing community and perceived biological and Health implications. Eur J Basic Appl Sci, 3(3)

Daud MK, Nafees M (2017) Drinking Water Quality Status and Contamination in Pakistan. BioMed Res Int. https://doi.org/10.1155/ 2017/7908183

Eline B, Gertjan G (2019) Water and health: From environmental pressures to integrated responses. Elseriver, Amsterdam. https://doi. org/10.1016/j.actatropica.2019.03.011

Gopal K, Kumar B (2020) Isotopes ( $\delta 18 \mathrm{O}, \delta \mathrm{D}$ and $3 \mathrm{H})$ variations in groundwater with emphasis on salinization in the state of Punjab, India. Sci Total Environ. https://doi.org/10.1016/j.scitotenv.2021. 148051

Harish B, Kotlia BS (2021) Sources of solute and hydrochemical analysis of Gangotri glacier meltwater. Water Cryosphere Clim Change Himal. https://doi.org/10.1007/978-3-030-67932-3_16

Jasrotia AS, Bhagat BD, Ajay Kumar T, Rajesh K (2012) Remote sensing and GIS approach for delineation of groundwater potential and groundwater quality zones of Western Doon Valley, Uttarakhand, India. J Indian Soc Remote Sens. https://doi.org/10.1007/ s12524-012-0220-9

Jasrotia AS, Ajay Kumar T, Upasna A, Bhagat BD (2018) Geoinformatics based groundwater quality assessment for domestic and irrigation uses of the Western Doon valley, Uttarakhand, India. Groundw Sustain Dev. https://doi.org/10.1016/j.gsd.2018.01.003

Kumar M, Avinash P (2012) A review of permissible limits of drinking water. Indian J Occup Environ Med. https://doi.org/10.4103/ 0019-5278.99696

Srivastava S, Saikrishna V (2018) Smartphone-based System for water quality analysis. Appl Water Sci. https://doi.org/10.1007/ s13201-018-0780-0

Siti Hajar BT (2015) Analysis of physiochemical parameters to evaluate the drinking water quality. J Chem. https://doi.org/10.1155/ $2015 / 716125$

Vijay SK (2016) Consequence of temperature, $\mathrm{pH}$, turbidity and dissolved oxygen water quality parameters. Int Adv Res J Sci Eng Technol. https://doi.org/10.17148/IARJSET.2016.3834

Webster D (2003) pH - Principles and Measurement. Encyclopedia of Food Sciences and Nutrition (Second Edition)

Zheng Z, Yuanling Z (2011) Research on the water quality monitoring system for Inland lakes based on remote sensing. Environ Sci Inf Appl Technol. https://doi.org/10.1016/j.proenv.2011.09.268

Publisher's Note Springer Nature remains neutral with regard to jurisdictional claims in published maps and institutional affiliations. 